\title{
Lipoteichoic acids from Staphylococcus aureus stimulate proliferation of human non-small-cell lung cancer cells in vitro
}

\author{
Katja Hattar ${ }^{1}$ - Christian P. Reinert ${ }^{1}$ - Ulf Sibelius ${ }^{1} \cdot$ Mira Y. Gökyildirim ${ }^{1}$ • \\ Florentine S. B. Subtil ${ }^{2} \cdot$ Jochen Wilhelm $^{3} \cdot$ Bastian Eul $^{1} \cdot$ Gabriele Dahlem $^{1}$. \\ Friedrich Grimminger ${ }^{1}$. Werner Seeger ${ }^{3,4} \cdot$ Ulrich Grandel $^{1,5}$
}

Received: 2 June 2016 / Accepted: 24 February 2017 / Published online: 17 March 2017

(c) The Author(s) 2017. This article is an open access publication

\begin{abstract}
Pulmonary infections are frequent complications in lung cancer and may worsen its outcome and survival. Inflammatory mediators are suspected to promote tumor growth in non-small-cell lung cancer (NSCLC). Hence, bacterial pathogens may affect lung cancer growth by activation of inflammatory signalling. Against this background, we investigated the effect of purified lipoteichoic acids (LTA) of Staphylococcus aureus (S. aureus) on cellular proliferation and liberation of interleukin (IL)-8 in the NSCLC cell lines A549 and H226. A549 as well as H226 cells constitutively expressed TLR-2 mRNA. Even in low concentrations, LTA induced a prominent increase in cellular proliferation of A549 cells as quantified by automatic cell counting. In parallel, metabolic activity of A549 cells was enhanced. The increase in proliferation was
\end{abstract}

Parts of the doctoral thesis of Christian P. Reinert are incorporated in this manuscript.

Electronic supplementary material The online version of this article (doi:10.1007/s00262-017-1980-4) contains supplementary material, which is available to authorized users.

Ulrich Grandel

ulrich.grandel@innere.med.uni-giessen.de

1 Department of Internal Medicine IV/V, University of Giessen and Marburg Lung Center (UGMLC), Klinikstrasse 33, Giessen, Germany

2 Department of Radiotherapy and Radiooncology, PhilippsUniversity, Marburg, Germany

3 Department of Internal Medicine II, University of Giessen and Marburg Lung Center (UGMLC), Giessen, Germany

4 Max-Planck Institute for Heart and Lung Research, Bad Nauheim, Germany

5 Asklepios Klinik Lich, Lich, Germany accompanied by an increase in IL- 8 mRNA expression and a dose- and time-dependent release of IL- 8 . Cellular proliferation as well as the release of IL-8 was dependent on specific ligation of TLR-2. Interestingly, targeting IL- 8 by neutralizing antibodies completely abolished the LTA-induced proliferation of A549 cells. The pro-proliferative effect of LTA could also be reproduced in the squamous NSCLC cell line H226. In summary, LTA of $S$. aureus induced proliferation of NSCLC cell lines of adeno- and squamous cell carcinoma origin. Ligation of TLR-2 followed by auto- or paracrine signalling by endogenously synthesized IL- 8 is centrally involved in LTA-induced tumor cell proliferation. Therefore, pulmonary infections may exert a direct pro-proliferative effect on lung cancer growth.

Keywords Lung cancer - Infection - Lipoteichoic acids . Tumor proliferation · Interleukin- $8 \cdot$ Toll-like-receptor-2

$\begin{array}{ll}\text { Abbreviations } \\ \text { DSMZ } & \begin{array}{l}\text { Deutsche Sammlung von Mikroorganismen } \\ \text { und Zellkulturen GmbH }\end{array} \\ \text { Lpp } & \begin{array}{l}\text { Lipopeptides } \\ \text { LTA }\end{array} \\ \text { Lipoteichoic acids } \\ & \begin{array}{l}\text { 3-(4, 5-Dimethylthiazol-2-yl)-5-(3- } \\ \text { carboxymethoxyphenyl)-2-(4-sulfophenyl)- }\end{array} \\ & \text { 2H-tetrazolium } \\ \text { NSCLC } & \text { Non-small-cell lung cancer } \\ \text { S. aureus } & \text { Staphylococcus aureus } \\ \text { STR } & \text { Short-tandem repeat }\end{array}$

\section{Introduction}

Lung cancer is the leading cause of cancer-related death in the western hemisphere [1]. In the course of the disease, 
patients frequently develop pulmonary infections which have been reported to reduce the median survival substantially [2]. It is not clear, whether this reduction in median survival is merely attributable to the clinical complications of pulmonary infections, or whether bacteria may directly stimulate lung cancer growth.

Although the most common pathogens found in NSCLC are of Gram-negative origin, Gram-positive germs such as Staphylococcus aureus (S. aureus) and Streptococcus pneumoniae account for about $25 \%$ of pulmonary infections in lung cancer patients and are the leading cause of septicemia in lung cancer [3]. Cell wall components of bacterial pathogens such as lipopolysaccharides, the so-called "endotoxin" of Gram-negative bacteria and their Gram-positive equivalents, lipoteichoic acids (LTA), peptidoglycanes and lipopeptides (Lpp) [4] are major bacterial pathogenicity factors. After ligation of LPS to the CD14 molecule [5], cellular activation is initiated by binding to toll-like receptors. It is widely accepted that TLR-4 confers responsiveness to LPS [6, 7] while TLR-2 seems to be the key receptor for LTA [8-10]. Once TLR-dependent signalling is initiated, a plethora of proinflammatory mediators such as cytokines and lipid mediators are released by immunocompetent cells $[8,11]$.

It is well established that persistent inflammation and inflammatory mediators can promote cancer growth [12-14]. In lung cancer, a clear pathogenic role has been attributed to chronic inflammatory diseases such as chronic obstructive pulmonary disease [15]. One early step in the development of lung cancer is the activation of inflammatory cascades resulting in synthesis of growth factors and cytokines such as TGF-ß, IL-1, and IL-8 [15]. Once lung cancer has developed, further tumor progression may be caused by inflammatory mediators [16]. Among these inflammatory mediators IL-8 is of special relevance, because in cultured NSCLC cells and in animal models of NSCLC IL-8 has been shown to promote tumor growth $[17,18]$. Moreover, in lung cancer patients, there is a clear correlation between IL-8 expression, tumor angiogenesis and overall survival [19].

Synthesis of IL-8 is induced in response to activation of TLRs in myeloid-derived cells such as macrophages and neutrophils [20, 21]. Interestingly, the expression of TLRs is not restricted to myeloid-derived cells. As TLRs are found in a variety of human cancers of epithelial origin, they could definitively play a role in cancer progression. In gastric cancer, the expression of different TLRs enables gastric carcinoma cells to interact with Helicobacter pylori [22], which is followed by the production of tumor-promoting factors such as IL-8 [23] and proliferation of cancer cells [24]. Remarkably, an up-regulation of TLR-4 expression was recently demonstrated in human adenocarcinoma of the lung in vivo and TLR-4 expression levels correlated with malignancy [25]. TLR-2 is equally expressed by NSCLC cells in vitro [26] and TLR-2 mRNA has been detected in the bronchoalveolar fluid of patients with NSCLC [27].

Thus, specific interactions between bacterial pathogens and tumor cells may actually occur in NSCLC. For LPS, enhancement of lung cancer tumor growth has been described in NSCLC cell lines and in xenograft and in orthotopic models of lung cancer [28, 29]. In contrast, the consequences of the interaction between lung cancer cells and LTA are less obvious.

In the current study, we investigated the effect of highly purified LTA from $S$. aureus on proliferation and metabolic activity in human NSCLC cell lines of adeno- and squamous cell carcinoma origin. In essence, we found that LTA is a pro-proliferative stimulus for the tumor cell lines. Cellular activation proceeded via ligation of TLR-2 and endogenously formed IL-8 turned out to be a key mediator in NSCLC proliferation induced by LTA.

\section{Materials and methods}

\section{Cell culture and authentication}

The human lung adenocarcinoma cell line A549 (ATCCCCL-185) as well as the human lung squamous carcinoma cell line H226 were obtained from the American Type Culture Collection (Rockville, MD, USA) and cultured at $37^{\circ} \mathrm{C}$ in a humidified atmosphere $(95 \%$ air, $5 \%$ $\mathrm{CO}_{2}$ ). Cells were used up to passage 40 . Cells were regularly checked for contamination with mycoplasma by the local department of microbiology by analysis of $16 \mathrm{~S} \mathrm{r}$ DNA followed by amplicon sequencing as previously described [30, 31]. Moreover, both cell lines used were subjected to authentication by the German Collection of Microorganisms and Cell Cultures ("Deutsche Sammlung von Mikroorganismen und Zellkulturen GmbH", DSMZ) by short-tandem repeat (STR) DNA profiling [32]. STR profiles of the currently used cell lines showed a full match with the respective reference STR profiles. Thus, the A549 and H226 cells used in the current study were derived from authentic cell cultures. All cell culture media and supplements were from Gibco (Eggenstein, Germany), and cell culture plasticware was from Greiner Bio-One (Frickenhausen, Germany). NSCLC cell lines were grown in Dulbecco's modified Eagle's medium (DMEM/F12), supplemented with $10 \%$ FCS, $2 \mathrm{mM}$ L-glutamine, $10^{5} \mathrm{U} / 1$ penicillin and $100 \mathrm{mg} / \mathrm{l}$ streptomycin (culture medium). Cells were grown to confluence and subcultured every 2-3 days at a split ratio of 1:10. 


\section{Assessment of cellular proliferation by cell counting}

A549 or H226 cells were seeded on 24-well plates $(15,000$ cells/well for A549 and 30,000 cells/well for H226) and maintained in culture medium for $24 \mathrm{~h}$ before stimulation with LTA ( $S$. aureus, purified, InvivoGen, San Diego, CA, USA) After removement of culture medium by two washing procedures with RPMI, cells were kept in DMEM/F12 supplemented with $1 \% \mathrm{FCS}$ at a total volume of $500 \mu \mathrm{l} /$ well. NSCLC cells were exposed to various concentrations of LTA or sham-incubation was performed (control). In an additional series of experiments in Fig. 4, function-blocking antibodies targeting TLR-2 (clone TL2.1, e-Bioscience, San Diego, CA, USA), TLR-4 (clone HTA 125, e-Bioscience, San Diego, CA, USA), or IL-8 (MAB 208, R\&D Systems, Wiesbaden, Germany) were applied simultaneously to LTA. Antibodies targeting TLRs were applied at $0.5 \mu \mathrm{g} / \mathrm{ml}$, whereas the neutralizing IL-8 antibody was used at $5 \mu \mathrm{g} / \mathrm{ml}$. At the end of the incubation period from 24 to $72 \mathrm{~h}$, medium was removed, cells were washed twice and subsequently treated with $0.5 \%$ trypsin-EDTA. Detached cells were resuspended in a stop-solution (PBS containing $20 \%$ FCS) and subsequently counted automatically by the cell counter-analyzer system CasyR Model TT (Innovatis AG, Reutlingen, Germany). Data were expressed as percentage of controls (sham-incubated cells), which were set to $100 \%$. Two technical replicates per sample were run in each independent experiment.

\section{MTS assay}

The MTS assay (CellTiter 96@ Aqueous One Solution Cell Proliferation Assay, Promega, Mannheim, Germany) quantifies the metabolic activity of cells. This assay is used to quantify cellular proliferation and is based upon the cleavage of the yellow 3-(4, 5-dimethylthiazol-2-yl)5-(3-carboxymethoxyphenyl)-2-(4-sulfophenyl)-2H-tetrazolium, inner salt (MTS) to purple formazan by metabolic active cells. A549 or H226 cells were seeded on 96-well plates (2500 cells/well for A549 and 5000 cells for H226) $24 \mathrm{~h}$ before stimulation with LTA in culture medium. After removement of culture medium and two washing procedures, cells were kept in DMEM/F12 supplemented with $1 \%$ FCS at a total volume of $200 \mu \mathrm{l} /$ well. Both NSCLC cell lines were stimulated with increasing concentrations of LTA for various time periods; alternatively, sham-incubated controls were run for each time period. $2.5 \mathrm{~h}$ before the end of the incubation period, $20 \mu$ l of MTS solution were added to each well and plates were incubated for another $2.5 \mathrm{~h}$ under light protection and continuous shaking. Then, absorbance was read at $490 \mathrm{~nm}$, background readings were subtracted from the sample wells and data were expressed as percentage of controls (sham-incubated cells) which were set to $100 \%$. Five technical replicates per sample were run in each independent experiment.

\section{Measurement of IL-8}

IL-8 was quantified from the cell supernatants of LTAstimulated A549 cells by ELISA technique. For these experiments, A549 cells $(15,000$ cells/well) were seeded on 24-well plates and grown to confluence. Confluent monolayers were washed twice and kept in DMEM/F12 with $1 \%$ FCS at a total volume of $500 \mu \mathrm{l} /$ well. Then, incubation with different concentrations of LTA or sham-incubation (control) was performed for various time periods. In a separate set of experiments, stimulation with LTA was performed in the absence or presence of antibodies targeting TLR- 2 and TLR-4. Two technical replicates per sample were run in each independent experiment. At the end of the incubation period, cell supernatants were harvested, cell debris was removed by centrifugation at $13.000 \times g$ and samples were stored at $-20^{\circ} \mathrm{C}$ until further processing. Release of IL-8 was determined in a direct sandwich ELISA, as described previously [33]. To normalize the data, IL-8 was expressed as $\Delta \mathrm{IL}-8$, meaning that baseline levels of IL-8 secreted from unstimulated controls were subtracted from those induced by stimulation with LTA.

\section{RNA isolation and real-time RT-PCR}

For quantification of IL-8 mRNA, experiments with A549 cells $(50,000$ cells/well) were performed as described above. Each independent experiment consisted of two technical replicates per sample.

Total RNA was extracted from cells with TRIzol Reagent (Invitrogen, Karlsruhe, Germany) according to the manufacturer's protocols. Extracted RNA was quantified with Nano Drop (PeqLab, Erlangen, Germany). Residual DNA was digested with DNase (Invitrogen, Karlsruhe, Germany) and cDNA was synthesized by RT (Bio-Rad, München, Germany). Real-time PCR was performed using $1 \mu \mathrm{g}$ of cDNA, SYBR Green PCR Master Mix (Bio-Rad, München, Germany) and $0.05 \mathrm{M}$ forward/reverse primers; specific primers used for sequence detection were as follows:

for $I L-8$ :

5'AGTTTTGCCAAGGAGTGCTAAA3' (forward) and 5'TGAATTCTCAGCCCTCTTCAAA3' (reverse).

for $P B G D$ :

5'CAGCTTGCTCGCATACAGAC3' (forward) and 5'GAATCTTGTCCCCTGTGGTG3' (reverse).

for TLR2:

5'AGCCTTGACCTGTCCAACAA3' (forward) and 5'GGCTTGAACCAGGAAGACGA3' (reverse). 
Real-time-reactions were carried out on the CFX Connect Real-Time PCR Detection System (Bio-Rad, München, Germany) with following cycle conditions: denaturation at $95^{\circ} \mathrm{C}$ for $3 \mathrm{~min} ; 40$ cycles with denaturation at $95^{\circ} \mathrm{C}$ for $10 \mathrm{~s}$, annealing at $59^{\circ} \mathrm{C}$ for $10 \mathrm{~s}$ and extension at $72^{\circ} \mathrm{C}$ for $10 \mathrm{~s}$. To ensure single-product amplification, a dissociation curve was generated for each gene and the threshold cycle ( $\mathrm{Ct}$ values) for each gene was determined.

Relative mRNA-levels were expressed as $\Delta \mathrm{Ct}$ values which were calculated with the genes $\mathrm{Ct}$ values normalized to the housekeeping gene PBGD $\mathrm{Ct}$ values. The comparative $2^{\wedge} \Delta \Delta \mathrm{Ct}$ method was used to analyze mRNA-fold changes between control and LTA, which was calculated as ratio $=2^{\wedge}(\Delta \mathrm{Ct}$ control $-\Delta \mathrm{Ct}$ LTA $)[28$, 34]. $\mathrm{Ct}$ is the cycle threshold and $\Delta \mathrm{Ct}$ ( $\mathrm{Ct}$ gene of interest-Ct housekeeping gene) is the CT value normalized to the housekeeping gene PBGD obtained for the same cDNA samples. The specificity of the primer pair products was tested by agarose (1.5\%) gel electrophoresis (Supplementary Fig. 1).

\section{Statistics}

Unlike otherwise indicated, data are given as the relative changes compared to control values and expressed as the mean \pm SEM. Data analysis was performed in $\mathrm{R}$ [35] using the packages "Ime4" and "ImerTest" [36]. Data were analyzed with linear mixed models to account for interexperimental differences. The variable "time" was taken as a factor in a two-factorial model together with "LTA concentration". Data were checked for the agreement with the model assumptions by analysis of the residuals. MTS activity data were inversely transformed before statistical analysis to meet the model assumptions. The diagrams show the means with SEM. The horizontal dashed line indicates the value of the unstimulated controls. For statistical analysis of changes in mRNA expression, student's $t$ test was performed. Groups or conditions with $p<0.05$ are marked with asterisks.

\section{Results}

\section{A549 and H226 cells express TLR-2 mRNA}

To confirm that the NSCLC cell lines used express TLR-2 as a prerequisite for specific interaction with LTA, we analyzed TLR- 2 mRNA by PCR. PDGD served as housekeeping gene. Unstimulated A549 and H226 cells were clearly positive for TLR-2 mRNA, as depicted in Table 1a. Interestingly, upon treatment with $0.1 \mu \mathrm{g} / \mathrm{ml}$ LTA for $24 \mathrm{~h}$, TLR-2 expression was doubled in A549 cells, whereas H226 cells did not show any up-regulation of TLR-2 mRNA after stimulation with LTA (Table 1b). Specificity of the primer pairs was visualized by agarose (1.5\%) gel electrophoresis (Supplementary Fig. 1).

\section{LTA induces proliferation of A549 cells}

A549 cells were stimulated with different concentrations of LTA $(0.01-1 \mu \mathrm{g} / \mathrm{ml})$ for various time periods $(24,48,72 \mathrm{~h})$ or sham-incubation was performed (baseline). The highly purified LTA preparation stimulated the proliferation of A549 cells in a time-dependent manner, as quantified by automatic cell counting (Fig. 1a). LTA-induced increase in proliferation is expressed as percentage of baseline levels, which was set to $100 \%$. Even low concentrations of LTA $(0.01 \mu \mathrm{g} / \mathrm{ml})$ were capable of inducing a significant increase in cellular proliferation. After 24 and $48 \mathrm{~h}$ of stimulation, all LTA concentrations induced increases in proliferation by $\sim 25$ to $35 \%$ of baseline levels. After $72 \mathrm{~h}$ of stimulation, increased proliferation was still observed when low $(0.01 \mu \mathrm{g} / \mathrm{ml})$ concentrations of LTA were used, whereas stimulation with $1 \mu \mathrm{g} / \mathrm{ml}$ LTA over this time period was ineffective. The most prominent increase in cellular proliferation was observed after stimulation with $0.1 \mu \mathrm{g} / \mathrm{ml}$ LTA for $48 \mathrm{~h}$ (increase by $35.36 \% \pm 1.25 \%$ of baseline levels).

Table 1 (a) Basal expression of TLR-2 mRNA in A549 and H226 cells $(n=4)$, (b) regulation of TLR-2 mRNA expression upon stimulation with LTA in A549 and H226 cells, $n=4$

\begin{tabular}{lll}
\hline (a) & A549, Ct & H226, Ct \\
\hline TLR-2 mRNA & $27.69 \pm 0.43$ & $27.70 \pm 0.39$ \\
PBGD mRNA & $21.41 \pm 0.18$ & $21.94 \pm 0.13$ \\
\hline (b) TLR-2mRNA & A549, fold-regulation & H226, fold regulation \\
\hline Control & 1 & 1 \\
LTA $0.1 \mu \mathrm{g} / \mathrm{ml}$ & $1.99 \pm 0.39 *$ & $0,90 \pm 0.20$ \\
\hline
\end{tabular}

$* p<0.05$ vs control 


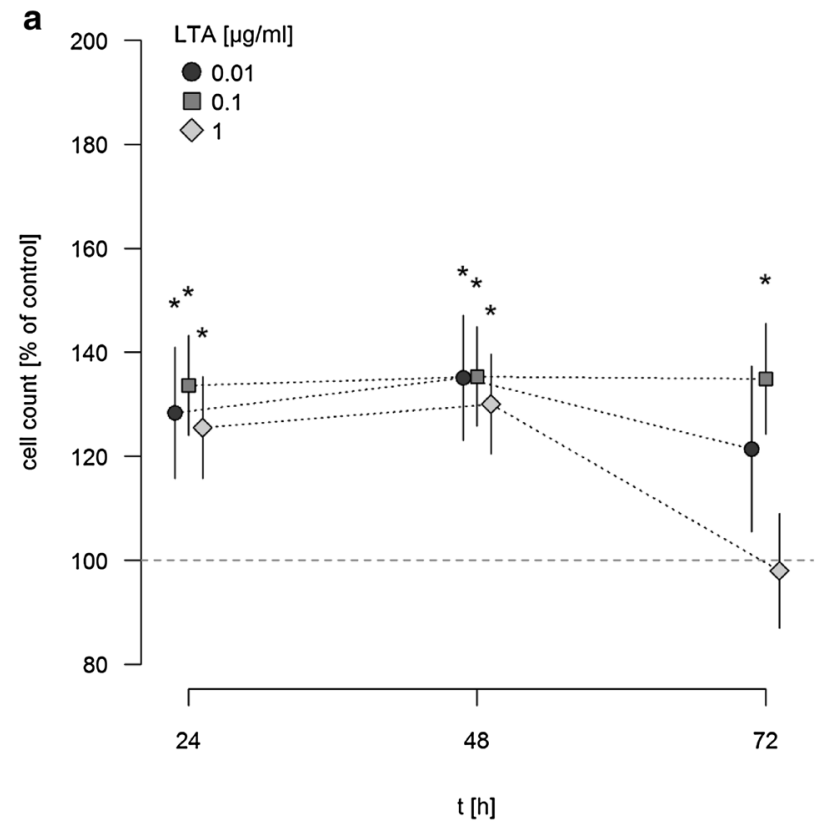

Fig. 1 Time-dependent induction of A549 proliferation and MTS activity by LTA. a A549 cells were incubated with various concentrations of LTA from S. aureus or sham-incubated (control). A549 proliferation was assessed by automatic cell counting. The horizontal dotted line indicates the baseline proliferation of sham-incubated cells, which was set to $100 \%$. All data are expressed as percentage of baseline proliferation. Means \pm SEM of at least seven independent experiments are given. Values marked with an asterisk differ

LTA failed to induce any pro-proliferative activity of A549 cells when applied at lower concentrations than $0.01 \mu \mathrm{g} / \mathrm{ml}$ : After $24 \mathrm{~h}$, proliferation rates were $105.1 \pm 2.7 \%$ of baseline upon stimulation with $0.001 \mu \mathrm{g} / \mathrm{ml}$ LTA and $103.4 \pm 2.9 \%$ after stimulation with $0.0001 \mu \mathrm{g} / \mathrm{ml}$ LTA $(n=5)$. Also after longer incubation periods with $0.001 \mu \mathrm{g} / \mathrm{ml}$ LTA and below, no significant pro-proliferative effect of LTA was observed (e.g. after $48 \mathrm{~h}$, proliferation induced by $0.001 \mu \mathrm{g} / \mathrm{ml}$ LTA was $105.5 \pm 0.7$ and $99.2 \pm 1.9 \%$ of baseline levels when $0.0001 \mu \mathrm{g} / \mathrm{ml}$ LTA were used, respectively, $n=5$ ).

The assessment of metabolic activity, as quantified by MTS assay, showed a comparable pro-proliferative effect of LTA on A549 cells (Fig. 1b). MTS activity was expressed as percentage of baseline levels, which was set to $100 \%$. After $6 \mathrm{~h}$ of incubation a significant increase in MTS activity, was noted after stimulation with $0.01 \mu \mathrm{g} / \mathrm{ml}$ LTA. After longer incubation periods of 24 and $48 \mathrm{~h}$, all LTA concentrations increased metabolic activity of A549 cells by $\sim 20$ to $25 \%$ of baseline levels. Just as observed by automatic cell counting, the most prominent increase in MTS activity of A549 cells was noted after stimulation by $0.1 \mu \mathrm{g} / \mathrm{ml}$ LTA for $48 \mathrm{~h}$ (increase by $26.9 \pm 1.8 \%$ of baseline levels).

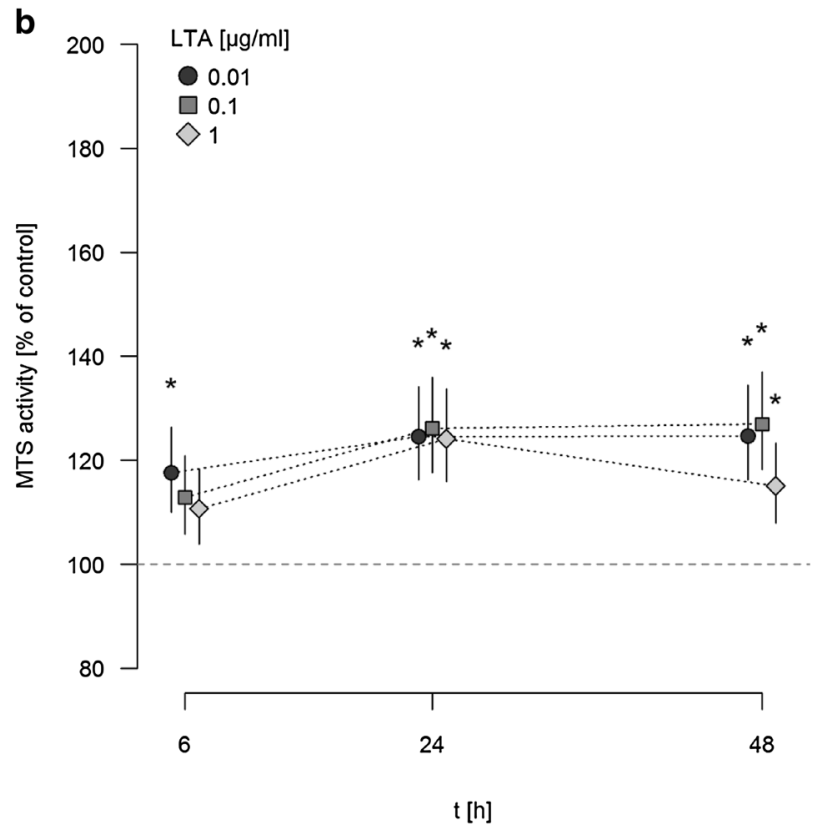

significantly from controls $(p<0.05)$. b A549 cells were incubated with various concentrations of LTA from $S$. aureus or sham-incubated (control). Metabolic activity of A549 cells was quantified by MTS assay. The horizontal dotted line indicates the baseline proliferation of sham-incubated cells, which was set to $100 \%$. All data are expressed as percentage of baseline proliferation. Means \pm SEM of at least seven independent experiments are given. Values marked with an asterisk differ significantly from controls $(p<0.05)$

\section{LTA induces a time- and dose-dependent release of IL-8 in a TLR-2-dependent manner}

When supernatants of LTA-activated A549 cells were analyzed for IL-8 release by ELISA, a dose-dependent release of this chemokine was noted upon stimulation with LTA (Fig. 2). IL-8 release was analyzed after 24, 48 , and $72 \mathrm{~h}$, and was expressed as $\Delta \mathrm{IL}-8$ versus baseline secretion at indicated time points. Baseline levels of IL-8 liberated from sham-stimulated A549 cells were 53, 98 and $83 \mathrm{pg} / \mathrm{ml}$ after 24,48 and $72 \mathrm{~h}$ respectively, and were increased by 117,129 and $214 \mathrm{pg} / \mathrm{ml}$ upon stimulation with $1 \mu \mathrm{g} / \mathrm{ml}$ LTA. In parallel, IL-8 mRNA was upregulated 3.50-fold in response to stimulation with $0.01,3.54$ fold upon stimulation with $0.1 \mu \mathrm{g} / \mathrm{ml}$, and 11.56-fold in response to $1 \mu \mathrm{g} / \mathrm{ml}$ LTA after $24 \mathrm{~h}$ as compared to shamincubated cells.

When ligation of TLR-2 was blocked by neutralizing antibodies, IL-8 release in response to $1 \mu \mathrm{g} / \mathrm{ml}$ LTA was strongly attenuated, as depicted for a stimulation period for $48 \mathrm{~h}$ in Fig. 3. In contrast, neutralizing TLR-4 had no inhibitory effect on LTA-induced release of this chemokine. 


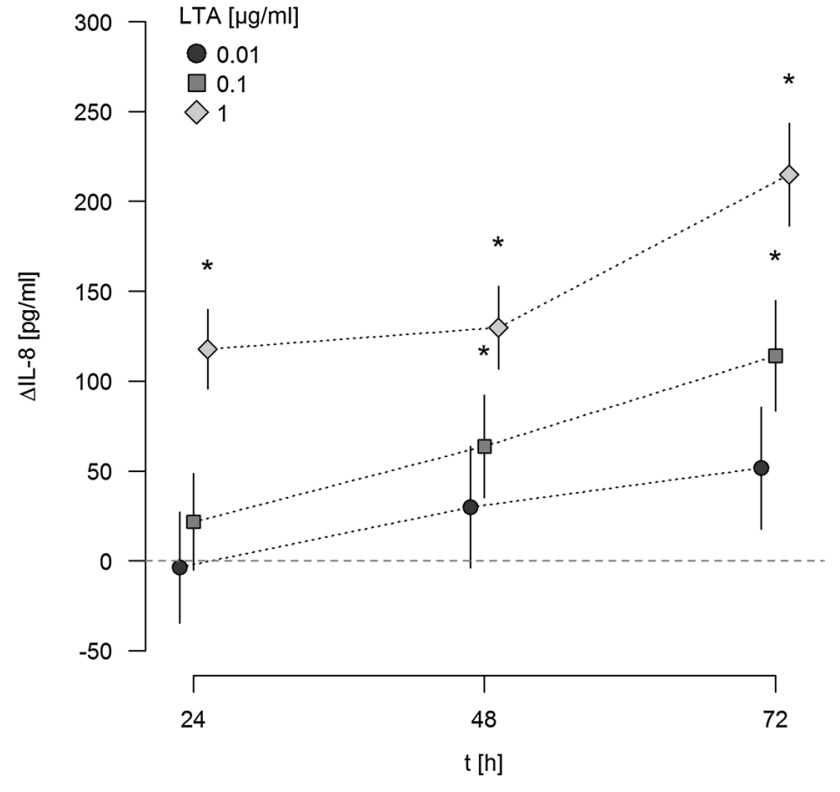

Fig. 2 Release of IL-8 from A549 cells in response to LTA. A549 cells were either sham-incubated (control) or exposed to the given concentrations of LTA. At indicated time points, cell supernatants were collected and analyzed for IL- 8 by ELISA technique. IL-8 release is given as $\Delta \mathrm{IL}-8$, which is the difference between IL-8 released from LTA-stimulated and sham-incubated cells (indicated by the horizontal dotted line). $\Delta \mathrm{IL}-8$ is expressed in $\mathrm{pg} / \mathrm{ml}$. Means \pm SEM of at least four independent experiments are given. Values marked with an asterisk differ significantly from controls $(p<0.05)$

\section{Mechanisms of LTA-induced A549 cell proliferation in vitro}

In order to determine the mechanism of LTA-stimulated A549 cellular proliferation, TLR-2, TLR-4 and IL-8 were blocked by antibodies under different experimental conditions. Concretely, stimulation with 0.1 and $1 \mu \mathrm{g} / \mathrm{ml}$ LTA was performed in the absence or presence of these neutralizing antibodies for 24 and $48 \mathrm{~h}$, and cellular proliferation was assessed by automatic cell counting. Stimulation of cellular proliferation induced by 0.1 and $1 \mu \mathrm{g} /$ $\mathrm{ml}$ LTA for $24 \mathrm{~h}$ was inhibited by interference with TLR2, whereas inhibition of TLR-4 had no effect (Fig. 4a/c). This inhibitory effect was still reproducible when stimulation with LTA $(0.1$ and $1 \mu \mathrm{g} / \mathrm{ml})$ was performed for $48 \mathrm{~h}$ (Fig. 4b/d). Most interestingly, neutralization of endogenously produced IL-8 abolished LTA-induced proliferation of A549 cells under all experimental conditions (Fig. 4 a-d). Exogenous IL-8 $(2 \mathrm{ng} / \mathrm{ml})$ induced a pro-proliferative response of $126.8 \pm 3.7 \%(n=6)$ as compared to baseline levels (100\%), which was not blocked by the presence of anti-TLR2-antibodies (increase in proliferation to $125.7 \pm 3.8 \%, n=6$ ), nor did the TLR-2 antibodies affect baseline proliferation (baseline proliferation

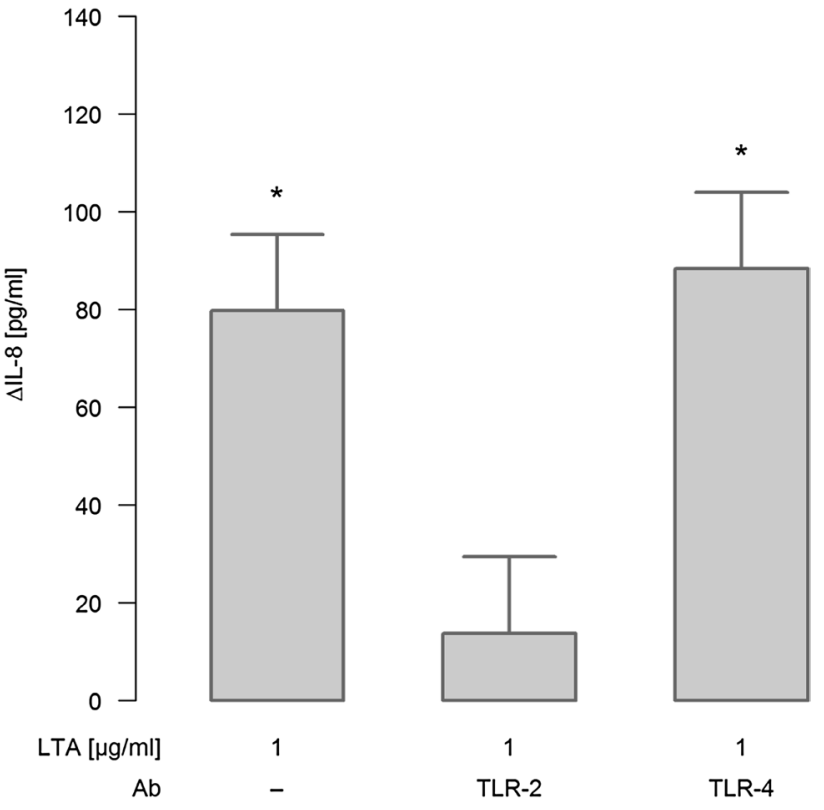

Fig. 3 Effect of TLR-2/-4 antagonists on LTA-induced synthesis of IL-8. A549 cells were either sham-incubated (control) or exposed to $1 \mu \mathrm{g} / \mathrm{ml}$ of LTA in the absence or presence of neutralizing antibodies targeting TLR- 2 or TLR- 4 for $48 \mathrm{~h}$. Release of IL- 8 into the cell supernatants was analyzed by ELISA technique and is given as $\Delta \mathrm{IL}-8$ $(\mathrm{pg} / \mathrm{ml})$, which was calculated by subtracting IL-8 values of shamincubated cells from LTA-stimulated cells. Data are expressed as means \pm SEM of at least six independent experiments. Values marked with an asterisk differ significantly from controls $(p<0.05)$

in the presence of TLR-2 antibodies was $100.7 \pm 2.2 \%$, $n=6)$.

\section{The pro-proliferative effects of LTA can be reproduced for the NSCLC squamous carcinoma cell line $\mathrm{H} 226$}

Finally, we tried to reproduce the pro-proliferative effect of LTA in a NSCLC cell line of squamous cell origin. For this purpose, $\mathrm{H} 226$ monolayers were stimulated with increasing concentrations of highly purified LTA $(0.01$, 0.1 , and $1 \mu \mathrm{g} / \mathrm{ml})$ for various time periods $(24,48,72 \mathrm{~h})$. As assessed by automatic cell counting, LTA induced proliferation of $\mathrm{H} 226$ cells approximately to the same extent as previously observed in A549 cells. A strong proliferative response in $\mathrm{H} 226$ cells was elicited even by the low LTA-concentration of $0.01 \mu \mathrm{g} / \mathrm{ml}$. Similar to A549 cells, lower concentrations of LTA did not exert any pro-proliferative effect (data not given). The proproliferative effect of LTA was observed over the whole incubation period of $72 \mathrm{~h}$. In parallel, MTS activity was enhanced upon stimulation with LTA, with an early response after $6 \mathrm{~h}$ of stimulation and an ongoing increase of MTS activity until $48 \mathrm{~h}$ (Fig. 5a/b). 

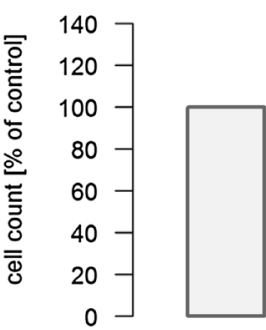

$\mathrm{LTA}[\mu \mathrm{g} / \mathrm{ml}]$
$24 \mathrm{~h}$
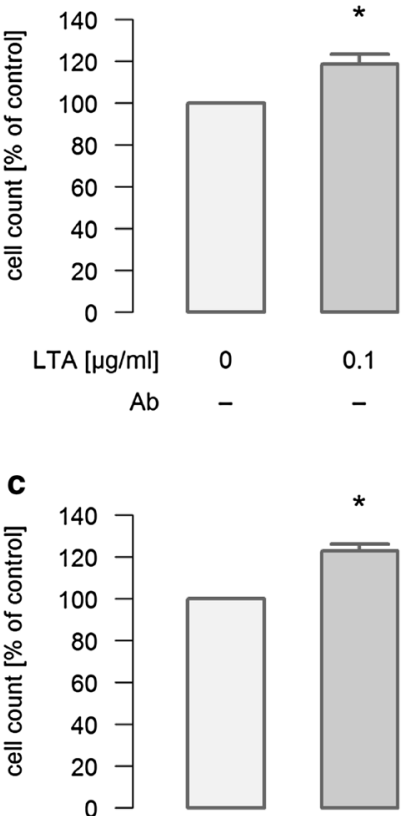

LTA $[\mu \mathrm{g} / \mathrm{m}$

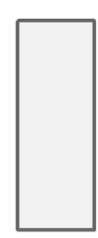

0
0.1

$-$

*

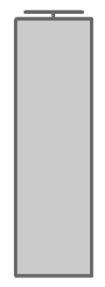

1

$\mathrm{Ab} \quad-$

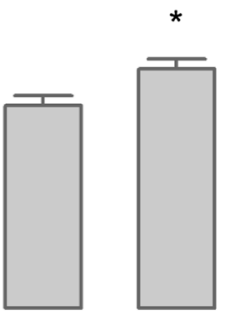

0.1

TLR-2

0.1

TLR-4

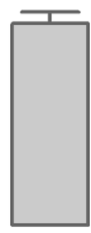

0.1

IL-8

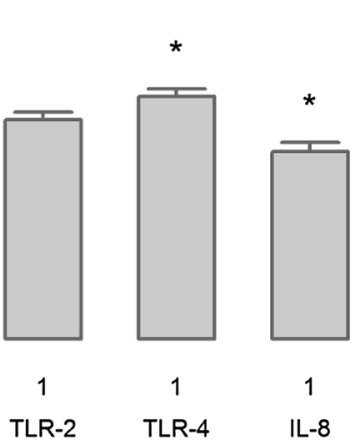

Fig. 4 Mechanisms of LTA-induced proliferation of A549 cells. A549 cells were either sham-incubated (control) or exposed to 0.1 $(\mathbf{a} / \mathbf{b})$ or $1 \mu \mathrm{g} / \mathrm{ml}(\mathbf{c} / \mathbf{d})$ of LTA for 24 or $48 \mathrm{~h}$ in the absence or presence of neutralizing antibodies targeting TLR-2, TLR-4 or IL-8. A549 proliferation was assessed by automatic cell counting. All data

\section{Discussion}

Pulmonary bacterial infections are frequently found in advanced stages of lung cancer and may contribute to the progression of this disease [2, 3]. In this context, bacterial pathogenicity factors may play a decisive role by stimulating cancer cell growth. While a strong pro-proliferative effect has been described for LPS, the endotoxin of Gramnegative bacteria, in lung, liver, ovarian, gastric and breast cancer [28, 29, 37-40], less is known about the pathogenicity factors of Gram-positive germs in this context.

In the present study, we observed that highly purified LTA from $S$. aureus induces proliferation in the lung adenocarcinoma cell line A549. The increase in cellular proliferation assessed by automatic cell counting was paralleled by an enhanced MTS activity. The increase in metabolic activity was clearly related to the increase in cell numbers thus confirming the observation that turnover of MTS is directly proportional to the numbers of viable cells in culture [41]. Notably, in both assays, LTA induced an increase in proliferation by $\sim 30 \%$, thus approaching or even exceeding the biological activity of other well-known endo- or exogenous proliferative agents such as IL-8 [17] or benzo[a]pyrene

b

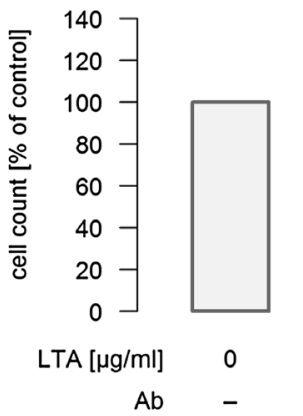

d

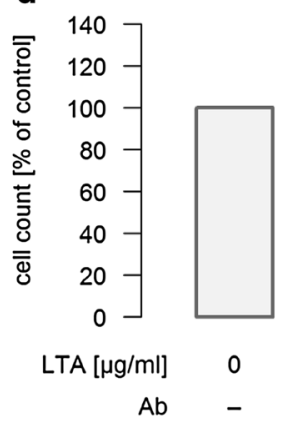

$48 \mathrm{~h}$

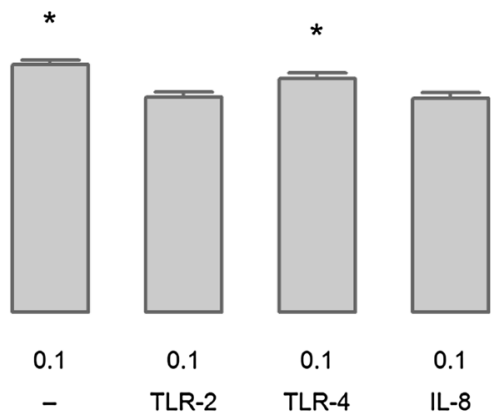

*
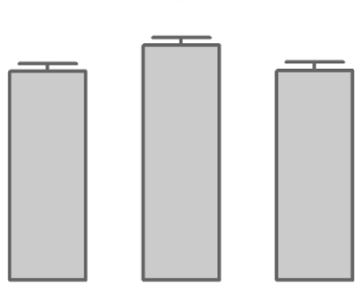

IL-8

are expressed as percentage of baseline proliferation of sham-incubated cells, which was set to $100 \%$. Means \pm SEM of at least four independent experiments are given. Values marked with an asterisk differ significantly from controls $(p<0.05)$

[42]. The pro-proliferative effect of LTA was not restricted to A549 cells but could be reproduced in a NSCLC line of squamous cell origin, suggesting a pathogenic role of LTA in lung cancer progression in general.

The pro-proliferative effects were clearly caused by LTA and not by contaminating LPS. First, we used highly purified LTA prepared according to the method of Morath et al. [43]. Second, compared to LPS much lower concentrations of LTA $(0.01 \mu \mathrm{g} / \mathrm{ml})$ were sufficient to stimulate cellular proliferation of A549 cells [28, 29]. Third, inhibition of TLR-4 by an antibody that effectively inhibited LPSinduced cellular responses [44, 45], did not affect the LTAinduced proliferation of the NSCLC cell line. And fourth, the LPS-induced pro-proliferative response in A549 cells displayed different kinetics compared to LPS, with a maximum response at $24 \mathrm{~h}$ and a rapid decline thereafter [28].

However, we cannot completely rule out that contamination with staphylococcal Lpp may have contributed, at least in part, to the biological activity of the LTA preparation used here. Despite broad evidence of the immunostimulatory potency of LTA [reviewed in 46], Lpp display some immune activation functions by ligation of TLR-2 [26], and some recent reports suggested that the immunostimulatory 


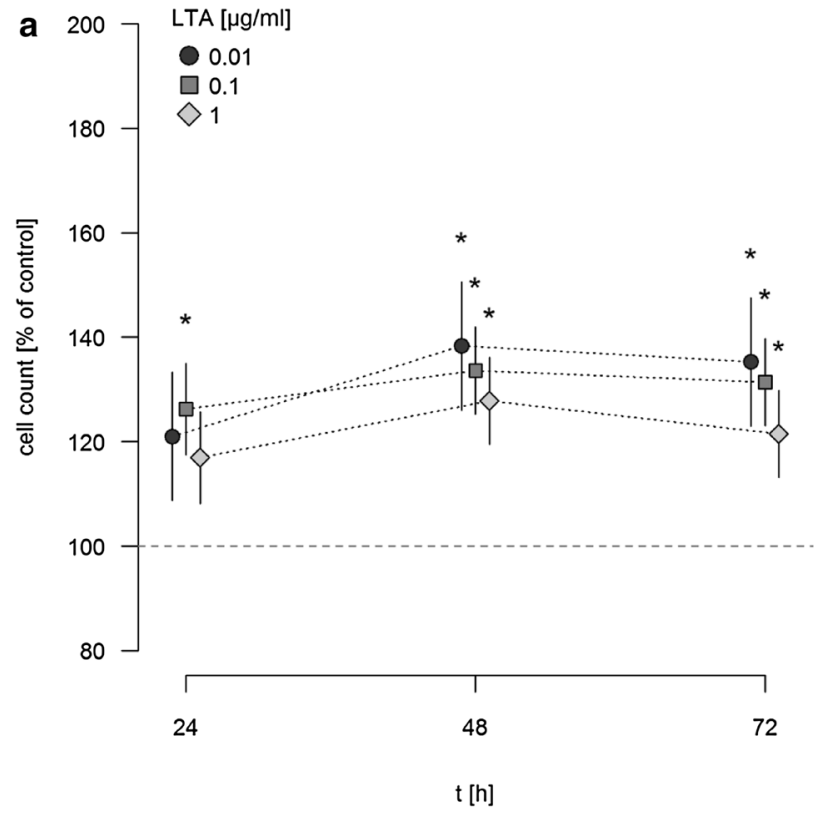

Fig. 5 Time-dependent increase in H226 proliferation and MTS activity by LTA. H226 cells were incubated with various concentrations of LTA from $S$. aureus or sham-incubation was performed (control). H226 proliferation was assessed by automatic cell counting (a) and metabolic activity was quantified by MTS assay (b). The horizon-

effects of LTA were, at least in part, mediated by contaminating Lpp [47, 48]. However, synthetic LTA has been demonstrated to activate cytokine synthesis [49] and in a recent report performed in full blood, it has also been shown that binding of LTA to TLR-2 is a prerequisite to elicit cytokine synthesis [50]. Thus, we believe that LTA is a potent activator of cellular inflammatory reactions.

It is noteworthy that, in contrast to LPS-induced stimulation $[28,29]$, LTA-mediated cellular proliferation displayed no clear dose-dependency. LTA-concentrations from 0.01 to $1 \mu \mathrm{g} / \mathrm{ml}$ induced proliferative responses. This observation is reminiscent of the "all or nothing" principle in human biology, which means that a cellular reaction is initiated as soon as a certain "threshold" concentration of receptor saturation is reached [51]. Therefore, one could speculate that TLR-2 receptors are "saturated" by $0.01 \mu \mathrm{g} /$ $\mathrm{ml}$ LTA, as lower concentrations of LTA failed to induce any significant pro-proliferative response. The absence of a clear dose-dependency in LTA-induced cellular proliferation corresponds well to the studies of Rezania et al., in which increased metabolic activity of human prostate cancer cell lines over a wide range of LTA-concentrations displayed no dose-dependency [10].

When higher concentrations of LTA $(1 \mu \mathrm{g} / \mathrm{ml})$ were used, cellular proliferation could not be further enhanced and was even reduced to baseline levels after the longest incubation period. This may be explained to the previously

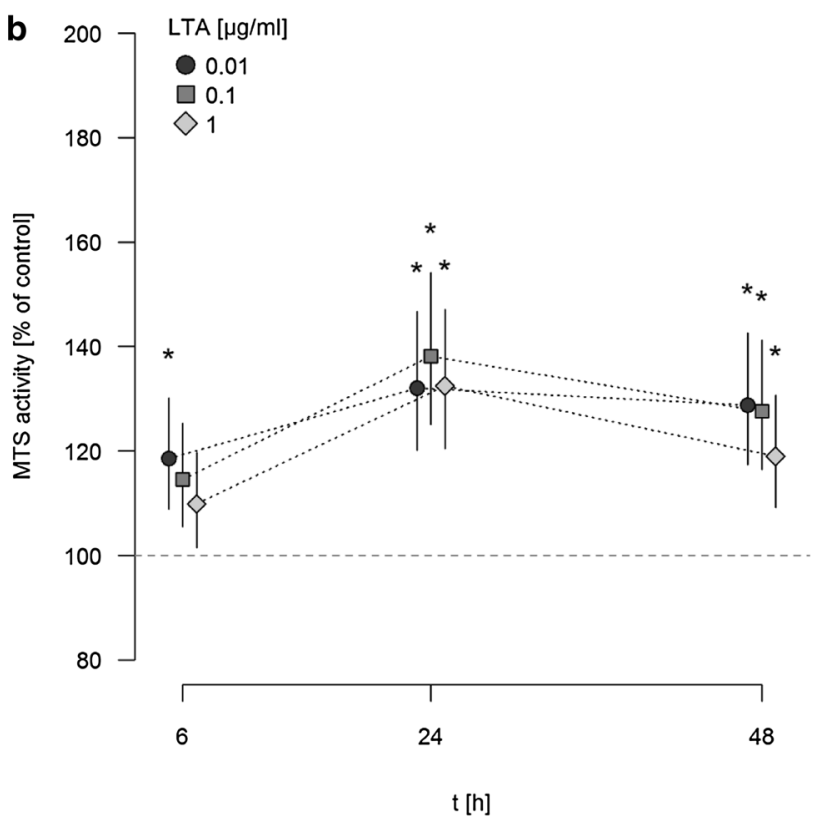

tal dotted line indicates the baseline proliferation (a) and MTS activity (b) of sham-incubated cells which was set to $100 \%$. All data are expressed as percentage of baseline proliferation. Means \pm SEM of at least four independent experiments are given. Values marked with an asterisk differ significantly from controls $(p<0.05)$

reported pro-apoptotic effects of LTA in high concentrations which may counteract the pro-proliferative effects of LTA at least in higher concentrations [52].

In our experimental setup LTA induced proliferation of A549 cells by a sequence of TLR-2 ligation, and subsequent activation of IL-8 synthesis. As a prerequisite for specific interaction with LTA, constitutive expression of TLR-2 mRNA was proven in both cell lines by real-time RT-PCR. Interestingly, LTA even induced up-regulation of TLR-2 mRNA in A549 cells. The relevance of TLR-2-expression was clearly demonstrated by the use of function blocking antibodies to TLR-2 and TLR-4. While LTAinduced release of IL-8 was abrogated in the presence of a TLR-2-antibody, blocking of TLR-4 did not affect IL-8 secretion in response to LTA. The specificity of the TLR-2 antibody was proven by the fact that it did not affect baseline or IL-8 induced proliferation of A549 cells. The TLR2-dependency of LTA-induced proliferation is in line with previous studies which demonstrated that LTA-induced cellular responses proceed via TLR-2 and further down-stream signaling involving pathway-specific TRAFs, activation of $\mathrm{NF}-\kappa \mathrm{B}$ and subsequent cytokine synthesis [8, 9, 53]. Supporting our findings, it has recently been demonstrated that TLR-2 activation is also operative in human gastric and breast cancer [54].

Clearly, biological activity of IL-8 was a prerequisite for A549 cell proliferation in our study. When IL-8 was 
inhibited by a neutralizing antibody proliferation of A549 cells in response to LTA was completely abolished. The observation that in the low concentration of LTA $(0.01 \mu \mathrm{g} /$ ml) no significant amounts of IL-8 were detected, does not stand against this mechanism, as there was still a trend towards elevated IL-8 levels. Moreover, IL- 8 mRNA was elevated nearly to the same extent whether 0.01 or $0.1 \mu \mathrm{g} /$ $\mathrm{ml}$ LTA were used. We assume that IL- 8 is liberated from A549 cells and activates adjacent A549 cells in an auto- or paracrine way without necessarily reaching significant concentrations in the cell supernatants under all experimental conditions.

Auto- and/or paracrine activation of A549 proliferation by IL-8 correspond well to the in-vitro-studies of Luppi et al., which demonstrated that exogenously added IL-8 stimulates proliferation in the NSCLC cell lines [55]. In line with these results, we demonstrated that addition of exogenous IL-8 stimulated A549 proliferation. Although we did not address the exact signaling events in our study, one mechanism of autocrine cell activation may be direct stimulation of the CXCR receptor type 1 , which has been shown to be the decisive receptor subtype mediating proliferative responses upon stimulation with IL-8 in A549 cells [56]. Alternatively, IL-8 may activate NSCLC growth by trans-activation of EGFR, one of the key "drivers" of NSCLC, especially when activating mutations are found [57]. The capacity of IL-8 to transactivate EGFR has not only been shown in A549 cells [55], but also in gastric epithelial and endothelial cells [58, 59]. Besides its direct effect of tumor cell activation, IL-8 is a potent pro-angiogenic factor in NSCLC $[18,19]$, which may be of further relevance in lung cancer patients.

In conclusion, this is the first study which demonstrates that purified LTA of $S$. aureus effectively induces growth of NSCLC cell lines of adeno- and squamous cell carcinoma origin. These effects are mediated by ligation of TLR-2, and IL-8 was identified as a decisive endogenous mediator activating tumor cell growth. Thus, infections with Grampositive bacteria may directly contribute to tumor growth in lung cancer.

Acknowledgements We cordially thank Prof. Eugen Domann and his co-workers from the Institute of Medical Microbiology, German Centre for Infection Research (DZIF Partner Site Giessen-MarburgLangen), Justus-Liebig-University, Schubertstrasse 81, D-35392 Giessen, Germany, for performing diagnostic assays to detect Mycoplasma species in the human NSCLC cell lines.

\section{Compliance with Ethical Standards}

Conflict of interest The authors declare that they have no conflict of interest.

Financial support This work was supported by the Emil von Behring and Wilhelm Conrad Röntgen Stiftung (BR 60-0004).
Open Access This article is distributed under the terms of the Creative Commons Attribution 4.0 International License (http:// creativecommons.org/licenses/by/4.0/), which permits unrestricted use, distribution, and reproduction in any medium, provided you give appropriate credit to the original author(s) and the source, provide a link to the Creative Commons license, and indicate if changes were made.

\section{References}

1. Siegel R, Ma J, Zou Z, Jemal A (2014) Cancer statistics. CA Cancer J Clin 64:9-29. doi:10.3322/caac.21208

2. Perlin E, Bang KM, Shah A, Hursey PD, Whittingham WL, Hashmi K, Campbell L, Kassim OD (1990) The impact of pulmonary infections on the survival of lung cancer patients. Cancer 66:593-596

3. Berghmans T, Sculier JP, Klastersky J (2003) A prospective study of infections in lung cancer patients admitted to the hospital. Chest 124:114-120

4. Pietrocola G, Arciola CR, Rindi S, Di Poto A, Missineo A, Montanaro L, Speziale P (2011) Toll-like receptors (TLRs) in innate immune defense against Staphylococcus aureus. Int J Artif Organs 34:799-810. doi:10.5301/ijao.5000030

5. Wright SD, Ramos RA, Tobias PS, Ulevitch RJ, Mathison JC (1990) CD14, a receptor for complexes of lipopolysaccharide (LPS) and LPS binding protein. Science 249:1431-1433

6. Qureshi ST, Lariviere L, Leveque G, Clermont S, Moore KJ, Gros P, Malo D (1999) Endotoxin-tolerant mice have mutations in Toll-like receptor 4. J Exp Med 189:615-619

7. Takeda K, Akira S (2005) Toll-like receptors in innate immunity. Int Immunol 17:1-14

8. Schwandner R, Dziarski R, Wesche H, Rothe M, Kirschning CJ (1999) Peptidoglycan- and lipoteichoic acid-induced cell activation is mediated by toll-like receptor 2 . J Biol Chem 274:17406-17409

9. Park OJ, Han JY, Baik JE, Jeon JH, Kang SS, Yun CH, Oh JW, Seo HS, Han SH (2013) Lipoteichoic acid of Enterococcus faecalis induces the expression of chemokines via TLR2 and PAFR signaling pathways. J Leukoc Biol 94:1275-1284. doi:10.1189/ jlb. 1012522

10. Rezania S, Amirmozaffari N, Rashidi N, Mirzadegan E, Zarei S, Ghasemi J, Zarei O, Katouzian L, Zarnani AH (2014) The same and not the same: heterogeneous functional activation of prostate tumor cells by TLR ligation. Cancer Cell Int 14: 54 . doi:10.1186/1475-2867-14-54

11. Draing C, Sigel S, Deininger S, Traub S, Munke R, Mayer C, Hareng L, Hartung T, von Aulock S, Hermann C (2008) Cytokine induction by Gram-positive bacteria. Immunobiology 213:285-296. doi:10.1016/j.imbio.2007.12.001

12. Coussens LW, Werb Z (2002) Inflammation and cancer. Nature 420:860-867

13. Mantovani A, Allavena P, Sica A, Balkwill F (2008) Cancer-related inflammation. Nature 454:436-444. doi:10.1038/ nature 07205

14. Colotta F, Allavena P, Sica A, Garlanda C, Mantovani A (2009) Cancer-related inflammation, the seventh hallmark of cancer: links to genetic instability. Carcinogenesis 30:1073-1081. doi:10.1093/carcin/bgp127

15. Adcock IM, Caramori G, Barnes PJ (2011) Chronic obstructive pulmonary disease and lung cancer: new molecular insights. Respiration 81:265-284. doi:10.1159/000324601

16. Rivas-Fuentes S, Salgado-Aguayo A, Pertuz Belloso S, Gorocica Rosete P, Alvarado-Vásquez N, Aquino-Jarquin G (2015) Role 
of chemokines in non-small cell lung cancer: angiogenesis and inflammation. J Cancer 6:938-952. doi:10.7150/jca.12286

17. Zhu YM, Webster SJ, Flower D, Woll PJ (2004) Interleukin-8/ CXCL8 is a growth factor for human lung cancer cells. Br J Cancer 91:1970-1976

18. Arenberg DA, Kunkel SL, Polverini PJ, Glass M, Burdick MD, Strieter RM (1996) Inhibition of interleukin-8 reduces tumorigenesis of human non-small cell lung cancer in SCID mice. $\mathrm{J}$ Clin Invest 97:2792-2802

19. Yuan A, Yang PC, Yu CJ, Chen WJ, Lin FY, Kuo SH, Luh KT (2000) Interleukin-8 messenger ribonucleic acid expression correlates with tumor progression, tumor angiogenesis, patient survival, and timing of relapse in non-small-cell lung cancer. Am J Respir Crit Care Med 162:1957-1963

20. Andreakos E, Sacre SM, Smith C, Lundberg A, Kiriakidis S, Stonehouse T, Monaco C, Feldmann M, Foxwell BM (2004) Distinct pathways of LPS-induced NF-kappa B activation and cytokine production in human myeloid and nonmyeloid cells defined by selective utilization of MyD88 and Mal/TIRAP. Blood 103:2229-2237

21. Kurt-Jones EA, Mandell L, Whitney C, Padgett A, Gosselin K, Newburger PE, Finberg RW (2002) Role of toll-like receptor 2 (TLR2) in neutrophil activation: GM-CSF enhances TLR2 expression and TLR2-mediated interleukin 8 responses in neutrophils. Blood 100:1860-1868

22. Schmausser B, Andrulis M, Endrich S, Müller-Hermelink HK, Eck M (2005) Toll-like receptors TLR4, TLR5 and TLR9 on gastric carcinoma cells: an implication for interaction with Helicobacter pylori. Int J Med Microbiol 295:179-185

23. Zhou C, Ma FZ, Deng XJ, Yuan H, Ma HS (2008) Lactobacilli inhibit interleukin-8 production induced by Helicobacter pylori lipopolysaccharide-activated Toll-like receptor 4. World J Gastroenterol 14:5090-5095

24. Yokota S, Okabayashi T, Rehli M, Fujii N, Amano K (2010) Helicobacter pylori lipopolysaccharides upregulate toll-like receptor 4 expression and proliferation of gastric epithelial cells via the MEK1/2-ERK1/2 mitogen-activated protein kinase pathway. Infect Immun 78:468-476. doi:10.1128/IAI.00903-09

25. Zhang YB, He FL, Fang M, Hua TF, Hu BD, Zhang ZH, Cao Q, Liu RY (2009) Increased expression of Toll-like receptors 4 and 9 in human lung cancer. Mol Biol Rep 36:1475-1481. doi:10.1007/s11033-008-9338-9

26. Charles PE, Tissières P, Barbar SD, Croisier D, Dufour J, DunnSiegrist I, Chavanet P, Pugin J (2011) Mild-stretch mechanical ventilation upregulates toll-like receptor 2 and sensitizes the lung to bacterial lipopeptide. Crit Care 15:R181. doi:10.1186/ cc10330

27. Samara KD, Antoniou KM, Karagiannis K, Margaritopoulos G, Lasithiotaki I, Koutala E, Siafakas NM (2012) Expression profiles of Toll-like receptors in non-small cell lung cancer and idiopathic pulmonary fibrosis. Int J Oncol 40:1397-1404. doi:10.3892/ijo.2012.1374

28. Hattar K, Savai R, Subtil FS, Wilhelm J, Schmall A, Lang DS, Goldmann T, Eul B, Dahlem G, Fink L, Schermuly RT, Banat GA, Sibelius U, Grimminger F, Vollmer E, Seeger W, Grandel U (2013) Endotoxin induces proliferation of NSCLC in vitro and in vivo: role of COX-2 and EGFR activation. Cancer Immunol Immunother 62:309-320. doi:10.1007/s00262-012-1341-2

29. Melkamu T, Qian X, Upadhyaya P, O'Sullivan MG, Kassie F (2013) Lipopolysaccharide enhances mouse lung tumorigenesis: a model for inflammation-driven lung cancer. Vet Pathol 50:895902. doi: $10.1177 / 0300985813476061$

30. Hauck EW, Domann E, Hauptmann A, Weidner W, Chakraborty T, Hossain HM (2003) Prospective analysis of 16 S rDNA as a highly sensitive marker for bacterial presence in Peyronie's disease plaques. J Urol 170:2053-2056
31. Domann E, Hong G, Imirzalioglu C, Turschner S, Kühle J, Watzel C, Hain T, Hossain H, Chakraborty T (2003) Culture-independent identification of pathogenic bacteria and polymicrobial infections in the genitourinary tract of renal transplant recipients. J Clin Microbiol 41:5500-5510

32. Dirks WG, MacLeod RA, Nakamura Y, Kohara A, Reid Y, Milch H, Drexler HG, Mizusawa H (2010) Cell line cross-contamination initiative: an interactive reference database of STR profiles covering common cancer cell lines. Int J Cancer 126:303-304. doi:10.1002/ijc.24999

33. Grandel U, Heygster D, Sibelius U, Fink L, Sigel S, Seeger W, Grimminger F, Hattar K (2009) Amplification of lipopolysaccharide-induced cytokine synthesis in non-small cell lung cancer/neutrophil cocultures. Mol Cancer Res 7:1729-1735. doi:10.1158/1541-7786

34. Kamlah F, Hänze J, Arenz A, Seay U, Hasan D, Juricko J, Bischoff B, Gottschald OR, Fournier C, Taucher-Scholz G, Scholz M, Seeger W, Engenhart-Cabillic R, Rose F (2011) Comparison of the effects of carbon ion and photon irradiation on the angiogenic response in human lung adenocarcinoma cells. Int J Radiat Oncol Biol Phys 80:1541-1549. doi:10.1016/j. ijrobp.2011.03.033

35. R Core Team (2014) R: a language and environment for statistical computing. R Foundation for Statistical Computing. https:// www.r-project.org/. Accessed 19 Feb 2015

36. Bates D, Maechler M, Bolker B, Walker S (2014) lme4: linear mixed-effects models using Eigen and S4. R package version 1.1-7. https://cran.r-project.org/web/packages/lme4/ Accessed 19 Feb 2015

37. Wang Y, Tu Q, Yan W, Xiao D, Zeng Z, Ouyang Y, Huang L, Cai J, Zeng X, Chen YJ, Liu A (2015) CXC195 suppresses proliferation and inflammatory response in LPS-induced human hepatocellular carcinoma cells via regulating TLR4-MyD88TAK1-mediated NF- $\mathrm{KB}$ and MAPK pathway. Biochem Biophys Res Commun 456:373-379. doi:10.1016/j.bbrc.2014.11.090

38. Szajnik M, Szczepanski MJ, Czystowska M, Elishaev E, Mandapathil M, Nowak-Markwitz E, Spaczynski M, Whiteside TL (2009) TLR4 signaling induced by lipopolysaccharide or paclitaxel regulates tumor survival and chemoresistance in ovarian cancer. Oncogene 28:4353-4363. doi:10.1038/onc.2009.289

39. Yang H, Wang B, Wang T, Xu L, He C, Wen H, Yan J, Su H, Zhu X (2014) Toll-like receptor 4 prompts human breast cancer cells invasiveness via lipopolysaccharide stimulation and is overexpressed in patients with lymph node metastasis. PLoS One 9:e109980. doi:10.1371/journal.pone.0109980

40. Li S, Xu X, Jiang M, Bi Y, Xu J, Han M (2015) Lipopolysaccharide induces inflammation and facilitates lung metastasis in a breast cancer model via the prostaglandin E2-EP2 pathway. Mol Med Rep 11: 4454-4462. doi:10.3892/mmr.2015.3258

41. Cory AH, Owen TC, Barltrop JA, Cory JG (1991) Use of an aqueous soluble tetrazolium/formazan assay for cell growth assays in culture. Cancer Commun 3: 207-212

42. Kometani T, Yoshino I, Miura N, Okazaki H, Ohba T, Takenaka T, Shoji F, Yano T, Maehara Y (2009) Benzo[a]pyrene promotes proliferation of human lung cancer cells by accelerating the epidermal growth factor receptor signaling pathway. Cancer Lett 278:27-33. doi:10.1016/j.canlet.2008.12.017

43. Morath S, von Aulock S, Hartung T (2005) Structure/function relationships of lipoteichoic acids. J Endotoxin Res 11:348-356

44. Paik YH, Schwabe RF, Bataller R, Russo MP, Jobin C, Brenner DA (2003) Toll-like receptor 4 mediates inflammatory signaling by bacterial lipopolysaccharide in human hepatic stellate cells. Hepatology 37:1043-1055

45. Xie XH, Law HK, Wang LJ, Li X, Yang XQ, Liu EM (2009) Lipopolysaccharide induces IL-6 production in respiratory syncytial virus-infected airway epithelial cells through the 
toll-like receptor 4 signaling pathway. Pediatr Res 65:156-162. doi:10.1203/PDR.0b013e318191f5c6

46. Rockel C, Hartung T (2012) Systematic review of membrane components of Gram-positive bacteria responsible as pyrogens for inducing human monocyte/macrophage cytokine release. Front Pharmacol 3:56. doi:10.3389/fphar.2012.00056

47. Hashimoto M, Furuyashiki M, Kaseya R, Fukada Y, Akimaru M, Aoyama K, Okuno T, Tamura T, Kirikae T, Kirikae F, Eiraku N, Morioka H, Fujimoto Y, Fukase K, Takashige K, Moriya Y, Kusumoto S, Suda Y (2007) Evidence of immunostimulating lipoprotein existing in the natural lipoteichoic acid fraction. Infect Immun 75:1926-1932

48. Zähringer $\mathrm{U}$, Lindner $\mathrm{B}$, Inamura $\mathrm{S}$, Heine $\mathrm{H}$, Alexander $\mathrm{C}$ (2008) TLR2 - promiscuous or specific? A critical re-evaluation of a receptor expressing apparent broad specificity. Immunobiology 213:205-224. doi:10.1016/j.imbio.2008.02.005

49. Morath S, Stadelmaier A, Geyer A, Schmidt RR, Hartung T (2002) Synthetic lipoteichoic acid from Staphylococcus aureus is a potent stimulus of cytokine release. J Exp Med 195:1635-1640

50. Bunk S, Sigel S, Metzdorf D, Sharif O, Triantafilou K, Triantafilou M, Hartung T, Knapp S, von Aulock S (2010) Internalization and coreceptor expression are critical for TLR2-mediated recognition of lipoteichoic acid in human peripheral blood. $\mathrm{J}$ Immunol 2010; 185: 3708-3717. doi:10.4049/jimmunol.0901660

51. Adrian ED (1914) The all-or-none principle in nerve. J Physiol 47:460-474

52. Tian Y, Zhang X, Zhang K, Song Z, Wang R, Huang S, Lin Z (2013) Effect of Enterococcus faecalis lipoteichoic acid on apoptosis in human osteoblast-like cells. J Endod 39:632-637. doi:10.1016/j.joen.2012.12.019

53. Hong SW, Baik JE, Kang SS, Yun CH, Seo DG, Han SH (2014) Lipoteichoic acid of Streptococcus mutans interacts with
Toll-like receptor 2 through the lipid moiety for induction of inflammatory mediators in murine macrophages. Mol Immunol 57:284-291. doi:10.1016/j.molimm.2013.10.004

54. Scheeren FA, Kuo AH, van Weele LJ, Cai S, Glykofridis I, Sikandar SS, Zabala M, Qian D, Lam JS, Johnston D, Volkmer JP, Sahoo D, van de Rijn M, Dirbas FM, Somlo G, Kalisky T, Rothenberg ME, Quake SR, Clarke MF (2014) A cell-intrinsic role for TLR2-MYD88 in intestinal and breast epithelia and oncogenesis. Nat Cell Biol 16:1238-1248. doi:10.1038/ncb3058

55. Luppi F, Longo AM, de Boer WI, Rabe KF, Hiemstra PS (2007) Interleukin- 8 stimulates cell proliferation in non-small cell lung cancer through epidermal growth factor receptor transactivation. Lung Cancer 56:25-33

56. Khan MN, Wang B, Wei J, Zhang Y, Li Q, Luan X, Cheng JW, Gordon JR, Li F, Liu H (2015) CXCR1/2 antagonism with CXCL8/Interleukin-8 analogue CXCL8(3-72)K11R/G31P restricts lung cancer growth by inhibiting tumor cell proliferation and suppressing angiogenesis. Oncotarget 6:21315-21327

57. Mok TS, Lee K, Leung L (2014) Targeting epidermal growth factor receptor in the management of lung cancer. Semin Oncol 41:101-109. doi:10.1053/j.seminoncol.2013.12.010

58. Joh T, Kataoka H, Tanida S, Watanabe K, Ohshima T, Sasaki M, Nakao H, Ohhara H, Higashiyama S, Itoh M (2005) Helicobacter pylori-stimulated interleukin-8 (IL-8) promotes cell proliferation through transactivation of epidermal growth factor receptor (EGFR) by disintegrin and metalloproteinase (ADAM) activation. Dig Dis Sci 50:2081-2089

59. Kyriakakis E, Cavallari M, Pfaff D, Fabbro D, Mestan J, Philippova M, De Libero G, Erne P, Resink TJ (2011) IL-8-mediated angiogenic responses of endothelial cells to lipid antigen activation of iNKT cells depend on EGFR transactivation. J Leukoc Biol 90:929-939. doi:10.1189/jlb.0211097 